\title{
Erratum to: Ecological genomics and conservation: where do we stand?
}

\author{
Gernot Segelbacher · Jacob Höglund
}

Published online: 4 March 2010

(C) Springer Science+Business Media B.V. 2010

Erratum to: Genetica (2009) 136:387-390

DOI 10.1007/s10709-008-9333-z

This article was intended for publication in the Special Issue of Ecological Genomics.
An error of classification during peer review process has prevented its inclusion in this special issue, as it has been published earlier in Volume 136, Number 3.

The online version of the original article can be found under doi: 10.1007/s10709-008-9333-z.

G. Segelbacher $(\bowtie)$

Department of Wildlife Ecology and Management, University of Freiburg, Tennenbacher Str. 4, 79106 Freiburg, Germany

e-mail: gernot.segelbacher@wildlife.uni-freiburg.de

J. Höglund

Population Biology and Conservation Biology, Department

of Ecology and Evolution, EBC, Norbyvägen 18D,

75236 Uppsala, Sweden 